\title{
Use of MALDI-TOF mass spectrometry for specificity studies of biomedically important proteases
}

\author{
Jüri Siigur*, Katrin Trummal, Külli Tõnismägi, Mari Samel, Ene Siigur, Heikki Vija, \\ Indrek Tammiste and Juhan Subbi \\ National Institute of Chemical Physics and Biophysics, Akadeemia tee 23, Tallinn, 12618, Estonia
}

\begin{abstract}
Proteases play crucial role starting from fertilization until to cell death. Our studies of the two Viperidae venoms (Levantine viper Vipera lebetina, Common viper Vipera berus) have demonstrated the existence of biomedically important proteases, both coagulants and anticoagulants that may be useful as diagnostic tools or potential therapeutics. We showed that venoms of both snakes contain: (i) metalloproteases and serine proteases that degrade fibrinogen, but not fibrin; (ii) factor $\mathrm{X}$ activators (VLFXA, VBFXAE); (iii) bradykinin-releasing serine proteases. Additionally Vipera lebetina snake venom contains thrombolytic fibrin degrading metalloenzyme (lebetase), HUVEC cell apoptosis inducing metalloprotease (VLAIP), factor V activator (VLFVA), thermostable $\beta$-fibrinogenase and $\alpha$-fibrinogenase which has no homolog among known serine proteases. We examined the activity of snake venom proteases against bradykinin, substance P, insulin B-chain and 6-10 amino acid residues containing peptides synthesized according to potential cleavage regions of fibrinogen, factor X, factor IX, factor V, $\alpha_{2}$-macroglobulin bait region and pregnancy zone protein (PZP). We used MALDI TOF mass spectrometry technique for the discovery and identification of peptides released by protease hydrolysis. The sensitive and quick MALDI-TOF mass spectrometry methodology allows us to obtain the primary information about the substrate specificity of different proteases against various peptides and proteins.
\end{abstract}

\section{Introduction}

Snake venoms, particularly those belonging to the Crotalidae and Viperidae families, contain a number of proteases that induce alterations in the blood coagulation cascade $[1,2,4-6,8,9,23,24]$. Proteases so far isolated from snake venoms are usually divided into two groups: (i) metalloproteases which need $\mathrm{Ca}^{2+}$ or $\mathrm{Zn}^{2+}$ (or both) for their hydrolytic activity and are inhibited by metal chelating agents (factor $\mathrm{X}$ activator, prothrombin activator, $\alpha(\beta)$-fibrinogenases, hemorrhagic proteases), (ii) serine proteases (factor $\mathrm{V}$ activator, protein $\mathrm{C}$ activator, plasminogen activator, kinin-releasing and thrombin-like enzymes, $\beta$-fibrinogenases). Recent studies revealed that some snake venoms contain factor $\mathrm{X}$ activators and prothrombin activators that are serine proteases [8]. Highly toxic hemorrhagic proteases degrade mammalian tissue proteins in a non-specific manner. A number of venom proteases cleave plasma proteins in relatively specific manner.

Zinc metalloproteases are widely occurring and participate in a number of important biological, physiological and pathophysiological processes (hemorrhage, fertilization, thrombolysis, cancer metastasis, etc.). Because of the possible therapeutic and diagnostic role of snake venom proteases, these enzymes merit further investigation. Vipera lebetina (Levantine viper) is a snake found in South-East parts of Europe, in South-West Asia and in North-West Africa. Vipera berus berus snake occurs in the whole

\footnotetext{
*Corresponding author. Tel.: +372 6398360; Fax: +372 6398313; E-mail: siigur@kbfi.ee.
} 
of Europe and in Asia. The venoms of these snakes contain various proteases [11-22], which act on coagulation through both pro- and anticoagulant mechanisms and also proteases acting on extracellular membranes causing hemorrhage.

$V$. lebetina and $V$. berus berus venoms contain different metalloproteases [12,13,16,18,20,22]. Snake venom metalloproteases have homologous sequences and typical active site structure for reprolysins HEXXHXXGXXH [1]. The primary structure of lebetase shows extensive sequence homology with fibrolase and with several other small snake venom metalloproteases [16]. However, the substrate specificity of snake venom proteases is rather different. Lebetase, a metalloprotease with thrombolytic activity, is a direct-acting fibrinolytic agent, as it acts via direct cleavage of fibrin, not by plasminogen activation. Lebetase has the typical active site for reprolysins. The enzyme readily hydrolyzes the $\mathrm{A} \alpha$ chain and more slowly the $\mathrm{B} \beta$ chain of fibrinogen. It was demonstrated that lebetase cleaves the "bait" region in $\alpha_{2}$-macroglobulin and hydrolyzes pregnancy zone protein (PZP) [10].

$V$. lebetina and $V$. berus berus venoms contain proteases that are able to activate factor $\mathrm{X}[13,20]$. During physiological haemostasis, factor $\mathrm{X}$ can be activated by factor IXa, requiring $\mathrm{Ca}^{2+}$, phospholipid, and factor VIIIa, or by factor VIIa requiring $\mathrm{Ca}^{2+}$ and tissue factor. Factor $\mathrm{X}$ is activated to the serine protease factor Xa. The activation results from the cleavage of the $\mathrm{Arg}^{52}-\mathrm{Il}^{53}$ bond in the heavy chain of human factor $\mathrm{X}$ and release of 52-residue activation peptide $[8,25]$.

The alkaline serine protease from $V$. lebetina venom - a nonfibrinolytic $\alpha$-fibrinogenase - has a unique specificity hydrolyzing casein but not arginine esters [14]. The enzymes degrading the $\beta$-chain of fibrinogen without fibrinolysis belong to serine proteinases. Vipera lebetina $\beta$-fibrinogenase is a typical representative of arginine esterases without caseinolytic activity [14]. Factor $\mathrm{V}$ activator from V. lebetina venom resembles the activator from Vipera russelli venom [15,17].

Due to potential use of snake venom proteases as diagnostic and thrombolytic agents, it is important to know their broader specificity against biologically active proteins and peptides. In this report we have studied the specificity of V. lebetina and V. berus berus proteases. The substrates used were oxidized insulin B chain, bradykinin, substance $\mathrm{P}$ and 6-10 amino acid residues containing peptides synthesized according to the literature provided protease cleavage regions in proteins such as human factor X, factor IX, factor $\mathrm{V}$, fibrinogen, $\alpha_{2}$-macroglobulin and pregnancy zone protein. The sensitive and quick MALDI-TOF mass spectrometry methodology has led us to use this technology to obtain the primary information on the enzyme cleavage sites in peptides.

\section{Materials and methods}

\subsection{Materials}

Bradykinin, Lys-bradykinin and substance $\mathrm{P}$ were purchased from Serva (Heidelberg, Germany). Ferulic acid, 2,5-dihydroxybenzoic acid (DHB), human factor X and fibrinogen were from Sigma (St. Louis, MO, USA), benzoyl-Ile-Glu-Gly-Arg-p-nitroanilide hydrochloride (S-2222) from Chromogenix (Mölndal, Sweden). ZipTipC18 and C4 were from Millipore Corporation. All other reagents used were of analytical grade.

\subsection{Purification of proteases}

The purification of lebetase [18], VLFXA [20], bradykinin-releasing enzymes [11,19], VBFXAE [13] have been described in our previous studies. VLAIP, VBFXAEI and VBFXAEII were purified using gel 
filtration, ion-exchange and affinity chromatography (unpublished). Enzymes were analyzed by SDSpolyacrylamide gel electrophoresis, isoelectric focusing, HPLC and MALDI TOF mass spectrometry.

\subsection{Fibrinogen degradation}

Specific cleavage of fibrinogen was shown on $5-15 \%$ polyacrylamide gels. One half $\mathrm{ml}$ of $1 \%$ fibrinogen solution was incubated with $25 \mu \mathrm{g}$ of enzyme at $37^{\circ} \mathrm{C}$ in $0.05 \mathrm{M}$ Tris-saline buffer (pH 7.4). At various time intervals, $50 \mu \mathrm{l}$ aliquots were withdrawn and added to $50 \mu \mathrm{l}$ of denaturing solution $(10 \mathrm{M}$ urea, $4 \%$ SDS, $4 \%$ 2-mercaptoethanol). The samples were reduced and denatured overnight at $37^{\circ} \mathrm{C}$ before being electrophoresed.

\subsection{Enzyme activities}

Caseinolytic activity was assayed by the method of Kunitz as modified by Mebs [7]. Bradykininreleasing activity was determined using heated human plasma $\left(56^{\circ} \mathrm{C}, 3 \mathrm{~h}\right)$ as substrate. Plasma was centrifuged and dialysed against $0.05 \mathrm{M}$ ammonium acetate. 5-10 $\mu \mathrm{l}$ of enzyme solution $(1 \mathrm{mg} / \mathrm{ml})$ was added to $200 \mu \mathrm{l}$ of treated plasma containing $1 \mathrm{mM}$ o-phenanthroline and the mixture was incubated at $37^{\circ} \mathrm{C}$ for $20 \mathrm{~min}$. The mixture was ultrafiltrated (Ultra spin ultrafilter, cut-off 10000 ). The kinin was detected in filtrate by MALDI-TOF mass spectrometry.

The activation effect of factor X by VLFXA was measured by the amidolytic activity of the factor Xa that was formed according to the method described by Hofmann and Bon [3]. Bovine or human factor $\mathrm{X}$ was used as substrate for VLFXA. Factor Xa activity was determined with S-2222 by recording the liberation of p-nitroaniline at $405 \mathrm{~nm}$. The degradation products of human factor X treated with VLFXA were detected by MALDI TOF MS.

\subsection{SDS-PAGE}

SDS-polyacrylamide gel electrophoresis was carried out in $10 \%$ and $12.5 \%$ gels and gradient gels. The following molecular mass indicators were used: bovine serum albumin $(67 \mathrm{kDa})$, ovalbumin $(43 \mathrm{kDa})$, bovine carbonic anhydrase $(29 \mathrm{kDa})$, soybean trypsin inhibitor $(20.1 \mathrm{kDa})$, cytochrome $\mathrm{C}(12.3 \mathrm{kDa})$. Staining was performed with Coomassie Brilliant Blue R250.

\subsection{Peptide synthesis}

All peptides were synthesized at the $100 \mu \mathrm{mol}$ scale on Applied Biosystems 431A Peptide Synthesizer using BOC (t-butyl-oxycarbonyl) chemistry as suggested by the manufacturer.

The purity of peptides was assessed by analytical reverse phase - high performance liquid chromatography (HPLC) and MALDI-TOF mass spectrometry.

\subsection{MALDI-TOF mass spectrometry}

The MALDI mass spectra were measured with a home-built gridless time-of-flight MALDI mass spectrometer designed for maximum flexibility in use (National Institute of Chemical Physics and Biophysics). Before MALDI-TOF analyses in some cases protein samples were purified from salts using ZipTip $\mathrm{C}_{4}$ or ZipTip $\mathrm{C}_{18}$ according to Millipore instructions. The matrix used for MALDI-TOF MS analyses of proteases, factor $\mathrm{X}$ and cleavage products of factor $\mathrm{X}$ was ferulic acid. Cytochrome $\mathrm{C}$ and bovine carbonic anhydrase was used for mass calibration. 


\subsection{Monitoring of the enzymatic reaction. MALDI-TOF mass spectrometry of peptides}

Peptide and peptide cleavage analyses by MALDI-TOF MS have been previously reported [26]. All peptide solutions were directly prepared in $0.1 \mathrm{M} \mathrm{NH}_{4} \mathrm{HCO}_{3}$, at concentrations of about $1-5 \mathrm{mg} / \mathrm{ml}$, and kept frozen at $-20^{\circ} \mathrm{C}$ until use. The enzymatic hydrolysis of peptides was carried out in $0.1 \mathrm{M}$ $\mathrm{NH}_{4} \mathrm{HCO}_{3}$, at $37^{\circ} \mathrm{C}$ in an eppendorf tube. In a typical experiment, $100 \mu \mathrm{l}$ of $0.1 \mathrm{M} \mathrm{NH}_{4} \mathrm{HCO}_{3}$ solution of substrate $(1 \mathrm{mg} / \mathrm{ml})$ in an eppendorf tube was thermally equilibrated to $37^{\circ} \mathrm{C}$ in the thermostated rack. The reaction was started by addition of $15 \mu \mathrm{l}$ of enzyme solution $\left(1 \mathrm{mg} / \mathrm{ml}\right.$ in $\left.0.1 \mathrm{M} \mathrm{NH}_{4} \mathrm{HCO}_{3}\right)$. At predetermined time intervals $\left(5 \mathrm{~min}, 0.5 \mathrm{~h}, 20 \mathrm{~h}\right.$ ), the aliquot $(10 \mu \mathrm{l})$ was diluted with $100 \mu \mathrm{l}$ of $\mathrm{H}_{2} \mathrm{O}$ and $2 \mu \mathrm{l}$ of $6 \mathrm{~N} \mathrm{HCl}$ was added to stop the reaction. One half $\mu \mathrm{l}$ of diluted mixture was used for MALDI-TOF mass spectrometry analysis. The matrix used for peptide analyses was 2,5-dihydroxybenzoic acid (DHB). $10 \mathrm{mg}$ of DHB was dissolved in $1 \mathrm{ml}$ of a 1:1 mixture of $0.1 \%$ trifluoroacetic acid and acetonitrile for sample preparation. One half $\mu \mathrm{l}$ of this mixture was deposited on a stainless steel probe tip, mixed there with $0.5 \mu \mathrm{l}$ of reaction mixture of peptides and enzyme and allowed to dry at room temperature. External mass calibration was accomplished by using as peptide standards, substance $\mathrm{P}$ and Lys-bradykinin.

For peptide analysis the mass spectrometer was operated in reflectron mode with $2.6 \mathrm{kV}$ pulsed extraction, $14.6 \mathrm{kV}$ total acceleration voltage and $500 \mathrm{~ns}$ delay between laser and extraction pulse. A double multichannel plate detector was used for ion detection.

\section{Results and discussion}

Viperidae venoms contain a lot of serine and metalloproteases. From V. lebetina venom following proteases were purified: fibrinolytic enzyme lebetase [18], factor X activator (VLFXA) [20], factor V activator (VLFVA) [17], bradykinin releasing enzymes [19] and HUVEC (human umbilical vein endothelial cell) apoptosis inducing protease (VLAIP); from $V$. berus berus venom: factor $\mathrm{X}$ activating proteases (VBFXAE [13], VBFXAEI, VBFXAEII) and bradykinin releasing enzymes [11]. Molecular masses of proteases, detected by MALDI TOF MS and SDS-PAGE, are provided in Table 1. Mass spectrum of VLAIP is given in Fig. 1. All proteases (except lebetase) are glycosylated [11-14,17].

Specificity of V. lebetina and V. berus berus venom metalloproteases was studied against different proteins and peptides. The most popular substrate for characterization of proteases is oxidized insulin B chain. In our previous studies $[12,13,18]$ we used amino acid analysis of proteolysis cleavage products of insulin B chain. The cleavage of insulin B chain by VLAIP, VBFXAEI and VBFXAE II was investigated using MALDI-TOF MS that is more effective and quick method for detection of peptide fragments. Lebetase [18], VBFXAE [13], VBFXAEI, VBFXAEII cleave Ala ${ }^{14}-\mathrm{Leu}^{15}$ and $\mathrm{Tyr}^{16}{ }^{16} \mathrm{Leu}^{17}$ bonds (Tables 2, 3; Fig. 2). VLAIP cleaves only Ala ${ }^{14}-$ Leu $^{15}$ bond (Fig. 3) and VLFXA does not hydrolyze insulin B-chain at all.

Substance $\mathrm{P}$ was cleaved by lebetase mainly at $\mathrm{Pro}^{4}-\mathrm{Gln}^{5}$ position [26]. The cleavage of substance $\mathrm{P}$ by VLAIP is rather different (Table 2). Lebetase cleavage sites in the "bait" region of $\alpha 2$-macroglobulin and PZP were determined by Edman degradation analysis of the digestion products [10]. Corresponding peptide fragments were used as substrates for lebetase [26] and VLAIP. Both enzymes cleave the same bonds in these peptides (Table 2).

Many snake venom proteases have fibrinogenolytic activities. Fibrinogen has often been used as substrate for various venom proteases $[1,5,18]$. V. lebetina and $V$. berus berus venom contain proteases (lebetase, VLAIP, VBFXAE, VBFXAEI, VBFXAEII) that cleave mainly A $\alpha$-chain of fibrinogen and more 
Table 1

Molecular masses of $V$. lebetina and $V$. berus berus proteases

\begin{tabular}{lcc}
\hline Enzyme & Nonreduced & Reduced \\
& $\mathrm{Da}$ & $\mathrm{Da}$ \\
\hline Lebetase & $22912[22]^{*}$ & $23700[18]$ \\
VLAIP & $106000^{*}$ & 60000 \\
VLFXA & $86500-91000[20]^{*}$ & $57500 ; 17400 ; 14500[20]$ \\
VLFVA & $28400[17]^{*}$ & $30000[17]$ \\
$\beta$-fibrinogenase & $42200[14]^{*}$ & 52500 \\
$\alpha$-fibrinogenase & $31100[14]^{*}$ & 37000 \\
VBFXAEI & 97500 & $56900 ; 16800 ; 12000$ \\
VBFXAEII & 125900 & 59300 \\
VBFXAE & $38000[13]$ & $38000[13]$ \\
\hline
\end{tabular}

* Detected by MALDI-TOF MS.

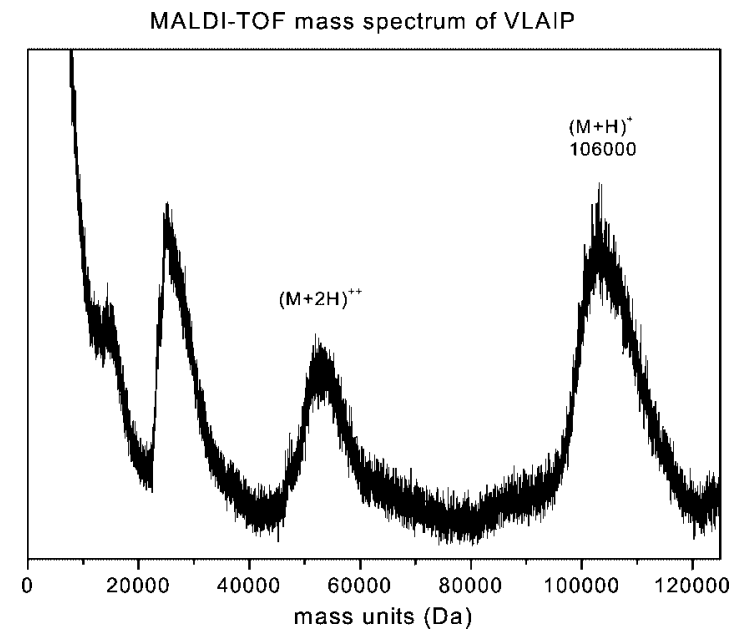

Fig. 1. MALDI-TOF mass spectrum of VLAIP. $(\mathrm{M}+\mathrm{H})^{+}$was indicated as the molecular ion while $(\mathrm{M}+2 \mathrm{H})^{++}$as double charged ions. Matrix was ferulic acid.

slowly B $\beta$-chain. V. lebetina venom $\alpha$-fibrinogenase degrades only A $\alpha$-chain [14]. None of them attacks $\gamma$-chain of fibrinogen. $V$. lebetina venom contains thermostable $\beta$-fibrinogenase that preferably cleaves $\beta$-chain of fibrinogen [14]. We have shown that cleavage patterns of fibrinogen treated with venom proteases are different $[14,18]$. We synthesized 6-10 amino acid containing peptide fragments according to fibrinogen A $\alpha$-chain cleavage site regions for various venom metalloproteases $\left(\mathrm{Lys}^{413}-\mathrm{Leu}^{414}\right.$, Pro ${ }^{516}$ $\mathrm{Met}^{517}$ ) [26]. These peptides were used as potential substrates for fibrinogenolytic metalloproteases. Lebetase cleaved the peptide EYHTEKLVTS at position Lys ${ }^{6}-$ Leu $^{7}$ and the peptide FFSPMLGE at position Pro $^{4}-\mathrm{Met}^{5}$ [26], the same positions are attacked also by VLAIP but the reaction is considerably slower (Table 2). VBFXAEI cleaved $\mathrm{Lys}^{6}-\mathrm{Leu}^{7}$ bond and more slowly $\mathrm{Tyr}^{2}-\mathrm{His}^{3}$ bond in EYHTEKLVTS, VBFXAEII catalyzed only the cleavage of $\mathrm{Lys}^{6}-\mathrm{Leu}^{7}$ bond (Table 3). Neither $V$. berus berus enzyme cleaved the peptide FFSPMLGE.

The purified factor X activator (VLFXA) from V. lebetina venom had no effect on fibrinogen, prothrombin, plasminogen, indicating that the activation of factor $X$ was specific [20]. The effects of VLFXA, VBFXAE, VBFXAEI and VBFXAEII on human factor $X$ were studied by measuring the ami- 
Table 2

Hydrolysis of peptide substrates by lebetase and VLAIP

\begin{tabular}{|c|c|c|}
\hline Name of substrate & Lebetase cleavage sites [26] & VLAIP cleavage sites \\
\hline \multicolumn{3}{|l|}{ Oxidized insulin B chain } \\
\hline FVNQHLC $\left(\mathrm{SO}_{3} \mathrm{H}\right) \mathrm{GSHLVEA}^{14} \mathrm{~L}^{15}$ & $\mathrm{Ala}^{14}-\mathrm{Leu}^{15}$ & $\mathrm{Ala}^{14}-\mathrm{Leu}^{15}$ \\
\hline $\mathrm{Y}^{16} \mathrm{~L}^{17} \mathrm{VC}\left(\mathrm{SO}_{3} \mathrm{H}\right)$ GERGFFYTPKA & $\mathrm{Tyr}^{16}-\mathrm{Leu}^{17}$ & \\
\hline \multicolumn{3}{|l|}{ Substance P } \\
\hline \multirow[t]{3}{*}{ RPKPQQFFGLM } & $*$ Pro $^{4}-G^{\prime} n^{5}$ & $\mathrm{Gln}^{5}-\mathrm{Gln}^{6}$ \\
\hline & Gly $^{9}-$ Leu $^{10}$ & $\mathrm{Phe}^{7}-\mathrm{Phe}^{8}$ \\
\hline & Pro $^{2}-$ Lys $^{3}$ & Gly $^{9}-$ Leu $^{10}$ \\
\hline \multicolumn{3}{|l|}{ Bradykinin } \\
\hline RPPGFSP $\downarrow$ FR & Pro $^{7}-\mathrm{Phe}^{8}$ & Pro $^{7}-\mathrm{Phe}^{8}$ \\
\hline \multicolumn{3}{|l|}{ Fibrinogen fragment $406-417$} \\
\hline HTEK $\downarrow$ LVTS & Lys $^{4}-$ Leu $^{5}$ & $\mathrm{Lys}^{4}-\mathrm{Leu}^{5}$ \\
\hline \multicolumn{3}{|l|}{ Fibrinogen fragment $513-520$} \\
\hline FFSP $\downarrow$ MLGE & Pro $^{4}-\mathrm{Met}^{5}$ & Pro $^{4}-\mathrm{Met}^{5}$ \\
\hline \multicolumn{3}{|l|}{$\alpha_{2}-\mathrm{M}$ fragment $693-700$} \\
\hline GHAR $\downarrow$ LVHV & $\operatorname{Arg}^{4}-\mathrm{Leu}^{5}$ & $\operatorname{Arg}^{4}-\mathrm{Leu}^{5}$ \\
\hline \multicolumn{3}{|l|}{$\alpha_{2}$-M fragment $676-684$} \\
\hline GPEG $\downarrow$ LRVGF & Gly $^{4}-$ Leu $^{5}$ & $\mathrm{Gly}^{4}-\mathrm{Leu}^{5}$ \\
\hline \multicolumn{3}{|l|}{ PZP fragment $686-693$} \\
\hline PYVP $\downarrow$ QLGT & Pro $^{5}-\mathrm{Gln}^{6}$ & Pro $^{5}-\mathrm{Gln}^{6}$ \\
\hline
\end{tabular}

${ }^{*}$ Pro $\downarrow$ Gln is the main cleavage site (after 5 min hydrolysis) of substance P by lebetase.

Table 3

Cleavage sites of peptides by factor X activating enzymes from Vipera berus berus venom

\begin{tabular}{|c|c|c|c|}
\hline Substrate & VBFXAEI & VBFXAEII & VBFXAE \\
\hline \multicolumn{4}{|l|}{ Oxidized insulin B-chain } \\
\hline FVNQHLC $\left(\mathrm{SO}_{3} \mathrm{H}\right) \mathrm{GSHLVEA}^{14} \mathrm{~L}^{15}$ - & Ala $^{14}-$ Leu $^{15}$ & Tyr $^{16}-$ Leu $^{17}$ & Tyr $^{16}-$ Leu $^{17}$ \\
\hline $\mathrm{Y}^{16} \mathrm{~L}^{17} \mathrm{VC}\left(\mathrm{SO}_{3} \mathrm{H}\right)$ GERGFFYTPKA & Tyr $^{16}-$ Leu $^{17}$ & $\mathrm{Ala}^{14}-\mathrm{Leu}^{15}$ & $\mathrm{Ala}^{14}-\mathrm{Leu}^{15}$ \\
\hline Factor $\mathrm{X}$ fragment & $\operatorname{Arg}^{5}-\mathrm{Ile}^{6}$ & Leu $^{3}-\mathrm{Thr}^{4}$ & Leu $^{3}-$ Thr $^{4}$ \\
\hline $\mathrm{NNL}^{3} \mathrm{~T}^{4} \mathrm{R}^{5} \mathrm{I}^{6} \mathrm{VGG}$ & $\mathrm{Leu}^{3}-\mathrm{Thr}^{4}$ & $\mathrm{Arg}^{5}-\mathrm{Ile}^{6}$ & $\mathrm{Arg}^{5}-\mathrm{Ile}^{6}$ \\
\hline Factor IX fragment & No cleavage & $\mathrm{Arg}^{5}-\mathrm{Val}^{6}$ & Not detected \\
\hline \multicolumn{4}{|l|}{$\mathrm{DFTR}^{5} \mathrm{~V}^{6} \mathrm{VGG}$} \\
\hline Fibrinogen $\mathrm{A} \alpha$-chain fragment & Lys $^{6}-$ Leu $^{7}$ & Lys $^{6}-$ Leu $^{7}$ & Not detected \\
\hline $\mathrm{EY}^{2} \mathrm{H}^{3} \mathrm{TEK}^{6} \mathrm{~L}^{7} \mathrm{VTS}$ & $\mathrm{Tyr}^{2}-\mathrm{His}^{3}$ & & \\
\hline
\end{tabular}

Preferably cleaved bonds are bold.

dolytic and the coagulant activities of the activated factor $\mathrm{X}$ (factor $\mathrm{X}_{\mathrm{a}}$ ). The activators convert the inactive factor $\mathrm{X}$ in the presence of $\mathrm{Ca}^{2+}$ ions to the active form Xa which activity was detected using substrate S-2222 in a complex two-stage reaction. The factor $\mathrm{X}$ activating enzymes themselves have no amidolytic activity against factor Xa substrate S-2222. To simplify the localization of factor X activators in the process of purification, 6-9 amino acid residues containing peptide fragments (TRIVGG, LTRIVGG and NNLTRIVGG) corresponding to the physiological cleavage region of human factor $\mathrm{X}$ were synthesized. VLFXA cleaved Arg-Ile bond in these peptides whereas the peptide NNLTRIVGG 


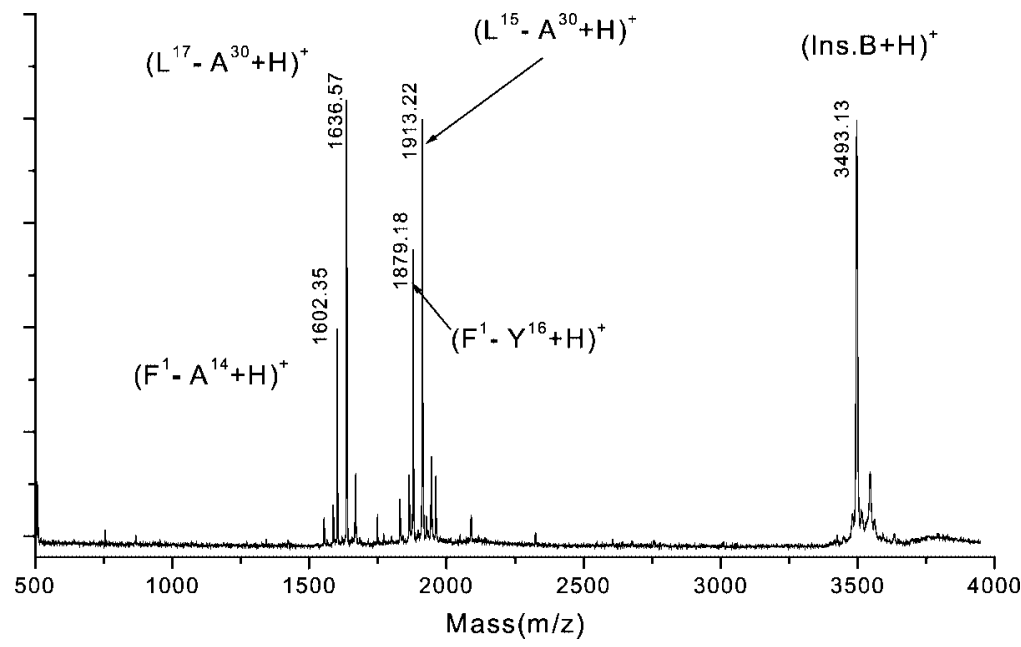

Fig. 2. MALDI-TOF mass spectrum of cleavage products of oxidized insulin B chain after 2 hours treatment with VBFXAE. Matrix was DHB.

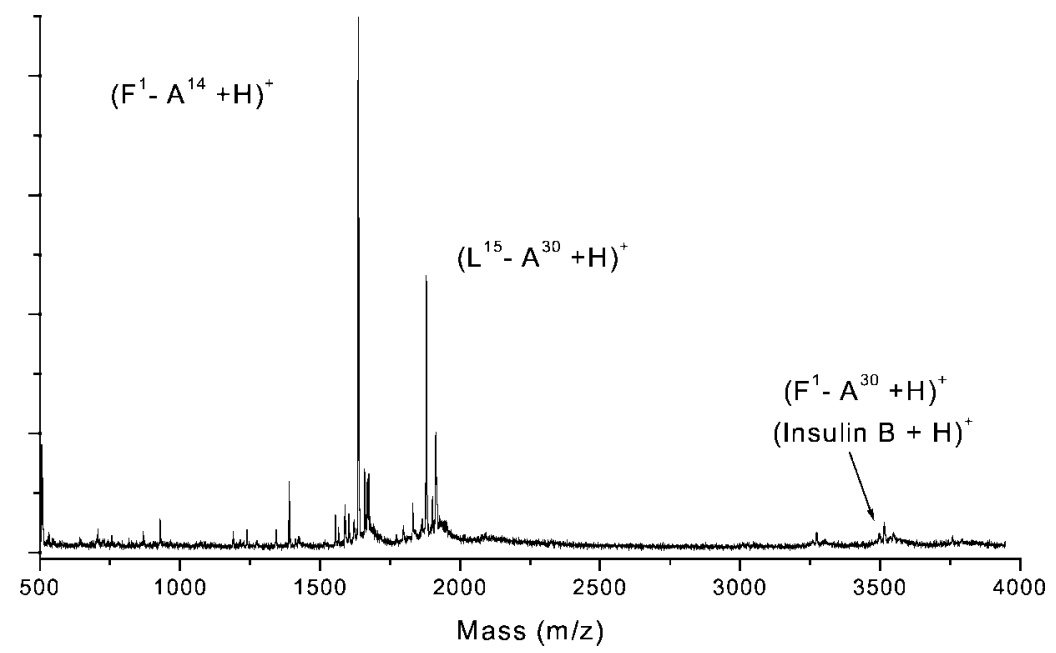

Fig. 3. MALDI-TOF mass spectrum of cleavage products of oxidized insulin B chain after 20 hours treatment with VLAIP. Matrix was DHB.

was the best substrate (Fig. 4). VLFXA may also activate factor IX while it hydrolyzed 9 amino acid residues containing peptide fragment NDFTRVVGG, synthesized according to the physiological cleavage region of human factor IX, in position Arg-Val [20].

Unlike VLFXA, $V$. berus berus venom factor X activating enzymes hydrolyze the peptide NNLTRIVGG at two positions: $\mathrm{Arg}^{5}-\mathrm{Ile}^{6}$ and $\mathrm{Leu}^{3}-\mathrm{Thr}^{4}$ whereas VBFXAEI catalyzes preferably $\mathrm{Arg}^{5}-\mathrm{Ile}^{6}$ bond and VBFXAE and VBFXAEII preferably Leu ${ }^{3}-\mathrm{Thr}^{4}$ bond (Table 3). The specificity studies of factor X activating enzymes from $V$. berus berus venom have shown that, besides factor $\mathrm{X}$, these enzymes cleave other proteins such as fibrinogen, asocasein and insulin B chain. However, all three enzymes release factor $X_{a}$ from human and bovine factor $X$, although the specific activities of $V$. berus berus venom enzymes are lower than these of RVV-X (V. russelli factor X activator [25]) and VLFXA. Consequently, $V$. berus berus venom factor $\mathrm{X}$ activating enzymes are nonspecific. 

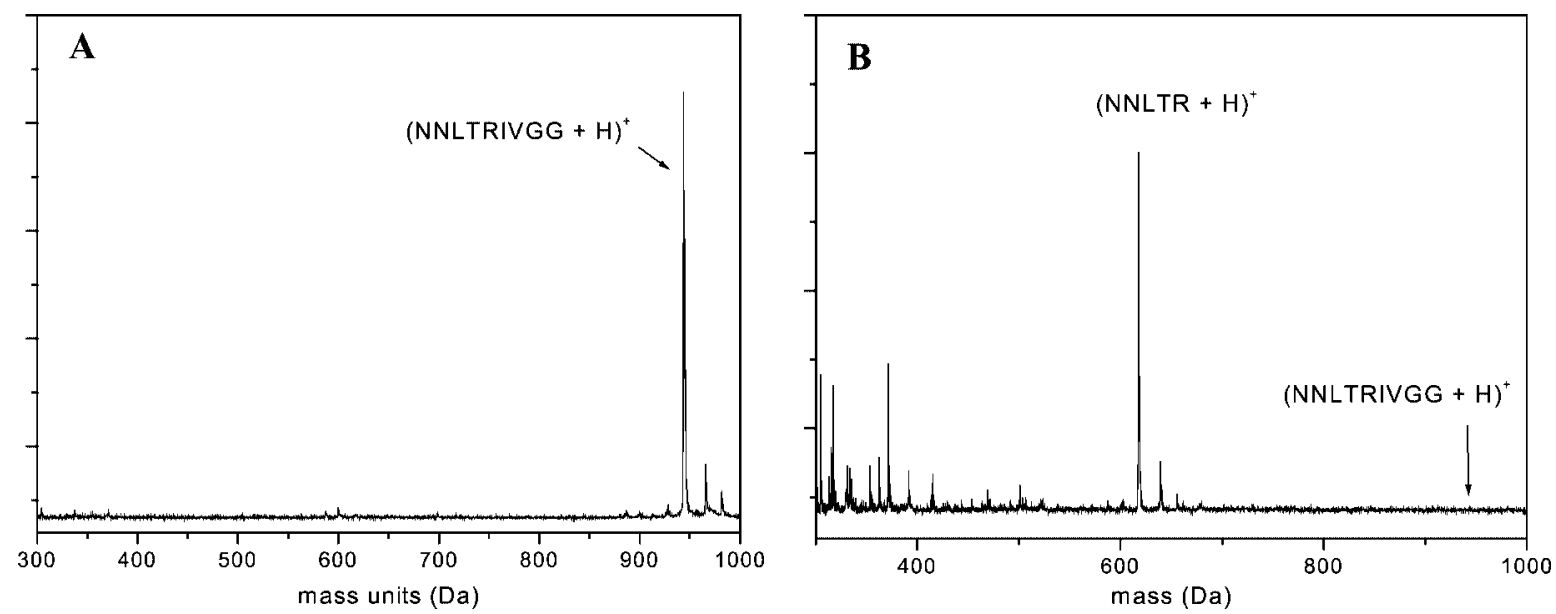

Fig. 4. (A) MALDI TOF mass spectrum of human factor X peptide fragment 48-56 NNLTRIVGG, (B) mass spectrum of cleavage products of human factor X peptide fragment after treating with VLFXA. Matrix was DHB.

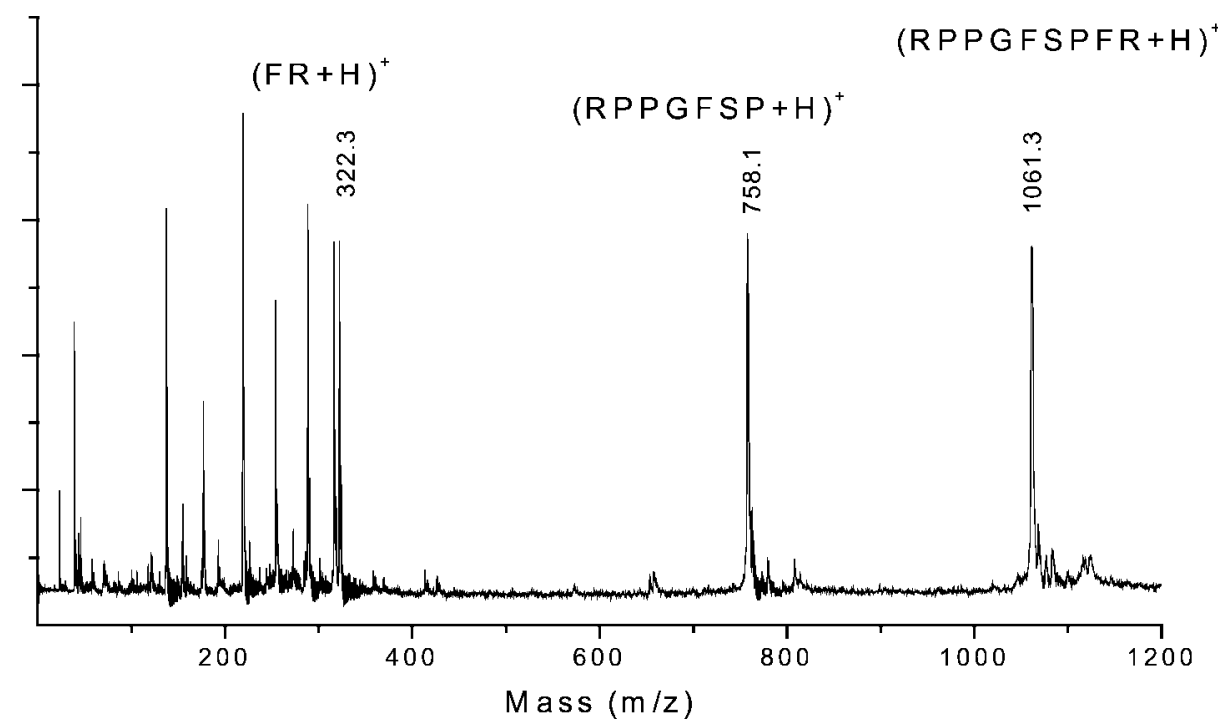

Fig. 5. MALDI-TOF mass spectrum of cleavage products of bradykinin after 5 minutes treatment with lebetase. Matrix was DHB.

VLFVA hydrolyzed human factor V peptide fragments containing 7-9 amino acids (YLRSNNG, WYLRSNNG and AWYLRSNNG), corresponding to $V$. russelli factor $\mathrm{V}$ activator cleavage region in human factor V. VLFVA cleaves Arg-Ser bond in these peptides [21].

We have shown that $V$. lebetina and $V$. berus berus venoms contain bradykinin-releasing serine enzymes [11,19]. MALDI TOF MS was very effective for detection of bradykinin that was liberated from human plasma after treating with bradykinin-releasing enzymes from V. lebetina [21] and V. berus berus venoms. This method successfully replaces the rat uterus test formely used for kinin detection. Bradykinin is a naturally occurring peptide that plays a role in maintenance of blood pressure. Thrombolytic enzyme lebetase cleaves bradykinin at the position $\mathrm{Pro}^{7}-\mathrm{Phe}^{8}[26]$, as well as the other metal- 
loprotease VLAIP does (Table 2). Cleavage of bradykinin by lebetase (an important side effect of the enzyme) destroys its biological activity. Viperidae venoms contain several serine proteases that release bradykinin and metalloproteases that cleave bradykinin, therefore the detection of bradykinin-releasing enzymes without metalloprotease inhibitors in crude venom is inaccurate.

The use of MALDI-TOF MS has several advantages over traditional methods for the elucidation of cleavage sites by proteases in peptides and proteins. MALDI-TOF MS has high sensitivity that allows the analysis of small aliquots removed from reaction mixture. Our results show that MALDI-TOF MS is a very informative tool and enables the characterization of the composition of cleaved peptides and proteins. However, as it stands now, MALDI is not quantitative enough for detecting kinetic parameters of enzyme reactions.

\section{Acknowledgements}

The work was financially supported by Estonian Science Foundation Grants No. 4228 and No.3842.

\section{References}

[1] J.B. Bjarnason and J.W. Fox, Snake venom metalloendopeptidases: Reprolysins, Methods Enzymol. 248 (1995), 345-368.

[2] S. Braud, C. Bon and A. Wisner, Snake venom proteins acting on hemostasis, Biochimie 82 (2000), 851-859.

[3] H. Hofmann and C. Bon, Blood coagulation induced by the venom of Bothrops atrox. 2. Identification, purification and properties of two factor X activators, Biochemistry 26 (1987), 780-787.

[4] F. Kornalik, Toxins affecting blood coagulation and fibrinolysis, in: Handbook of Toxinology, W.T. Shier and D. Mebs, eds, Marcel Dekker, Inc., New York and Basel, 1990, pp. 683-759.

[5] F.S. Markland, Snake venoms and hemostatic system, Toxicon 36 (1998), 1749-1800.

[6] T. Matsui, Y. Fujimura and K. Titani, Snake venom proteases affecting hemostasis and thrombosis, Biochim. Biophys. Acta 1477 (2000), 146-156.

[7] D. Mebs, A comparative study of enzyme activities in snake venoms, Int. J. Biochem. 1 (1970), 335-342.

[8] T. Morita, Proteases which activate factor X, in: Enzymes from Snake Venom, G.S. Bailey, ed., Alaken Inc., Fort Collins, Colorado, 1998, pp. 179-208.

[9] C. Ouyang, C.M.T. Teng and F. Huang, Characterization of snake venom components acting on blood coagulation and platelet function, Toxicon 30 (1992), 945-966.

[10] N. Saidi, M. Samel, J. Siigur and P.E.H. Jensen, Lebetase, an $\alpha(\beta)$-fibrin(ogen)olytic metalloproteinase of Vipera lebetina snake venom, is inhibited by human $\alpha$-macroglobulins. Biochim. Biophys. Acta 1434 (1999), 94-102

[11] M. Samel, E. Siigur and J. Siigur, Purification and characterization of two arginine hydrolases from Vipera berus berus (common viper) venom, Toxicon 25 (1987), 379-388.

[12] M. Samel and J. Siigur, Isolation and characterization of hemorrhagic metalloproteinase from Vipera berus berus (common viper) venom, Comp. Biochem. Physiol. 97C (1990), 209-214.

[13] M. Samel and J. Siigur, Medium molecular weight factor X activating enzyme from Vipera berus berus venom, Toxicon 33 (1995), 41-52.

[14] M. Samel, J. Subbi, J. Siigur and E. Siigur, Biochemical characterization of fibrinogenolytic serine proteinases from Vipera lebetina snake venom, Toxicon 40 (2002), 51-54.

[15] E. Siigur, A. Aaspõllu and J. Siigur, Molecular cloning and sequence analysis of a cDNA for factor V activating enzyme, a coagulant protein from Vipera lebetina snake venom, Biochem. Biophys. Res. Commun. 262 (1999), 328-332.

[16] E. Siigur, A. Aaspõllu, A.T. Tu and J. Siigur, cDNA cloning and deduced amino acid sequence of fibrinolytic enzyme (lebetase) from Vipera lebetina snake venom, Biochem. Biophys. Res. Commun. 224 (1996), 229-236.

[17] E. Siigur, M. Samel, K. Tõnismägi, J. Subbi, T. Reintamm and J. Siigur, Isolation, properties and N-terminal amino acid sequence of a factor V activator from Vipera lebetina (Levantine viper) snake venom, Biochim. Biophys. Acta 1429 (1998), $239-248$.

[18] E. Siigur and J. Siigur, Purification and characterization of lebetase, a fibrinolytic enzyme from Vipera lebetina (snake) venom, Biochim. Biophys. Acta 1074 (1991), 223-229.

[19] E.P. Siigur, J.R. Siigur, A.A. Aaviksaar, V.K. Kibirev and D.M. Fedoryak, Separation of a bradykinin-releasing enzyme from the proteolytic complex of Levantine viper, Biokhimiya (Russ.) 47 (1982), 1730-1737. 
[20] E. Siigur, K. Tõnismägi, K. Trummal, M. Samel, H. Vija, J. Subbi and J. Siigur, Factor X activator from Vipera lebetina snake venom, molecular characterization and substrate specificity, Biochim. Biophys. Acta 1568 (2001), 90-98.

[21] J. Siigur, A. Aaspõllu, K. Tõnismägi, K. Trummal, M. Samel, H. Vija, J. Subbi and E. Siigur, Proteases from Vipera lebetina venom affecting coagulation and fibrinolysis, Haemostasis 31 (2001), 123-132.

[22] J. Siigur, M. Samel, K. Tõnismägi, J. Subbi, E. Siigur and A.T. Tu, Biochemical characterization of lebetase, a directacting fibrinolytic enzyme from Vipera lebetina snake venom, Thromb. Res. 90 (1998), 39-49.

[23] J. Siigur and E. Siigur, The direct-acting $\alpha$-fibrin(ogen)olytic enzymes from snake venoms, J. Toxicol.-Toxin Reviews 11 (1992), 91-113.

[24] K. Stocker, Snake venom proteins affecting hemostasis and fibrinolysis, in: Medical Use of Snake Venom Proteins, K. Stocker, ed., CRC Press, Boca Raton, Ann Arbor, Boston, 1990, pp. 97-160.

[25] H. Takeya, S. Nishida, T. Miyata, S. Kawada, Y. Saisaka, T. Morita and S. Iwanaga, Coagulation factor X activating enzyme from Russell's viper venom (RVV-X). A novel metalloproteinase with disintegrin (platelet aggregation inhibitor)like and C-type lectin-like domains, J. Biol. Chem. 267 (1992), 14 109-14 117.

[26] K. Trummal, H. Vija, J. Subbi and J. Siigur, MALDI-TOF mass spectrometry analysis of substrate specificity of lebetase, a direct-acting fibrinolytic metalloproteinase from Vipera lebetina snake venom, Biochim. Biophys. Acta 1476 (2000), 331-336. 


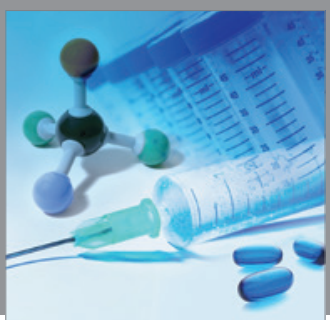

International Journal of

Medicinal Chemistry

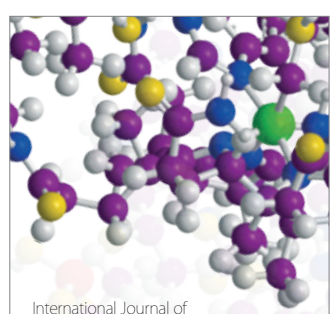

Carbohydrate Chemistry

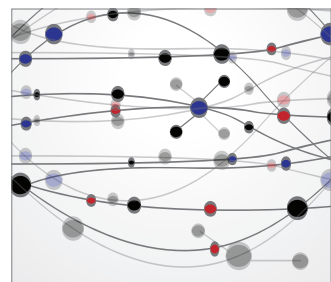

The Scientific World Journal
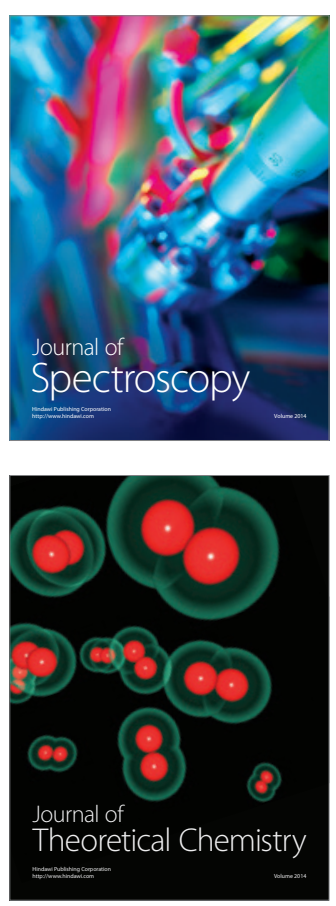
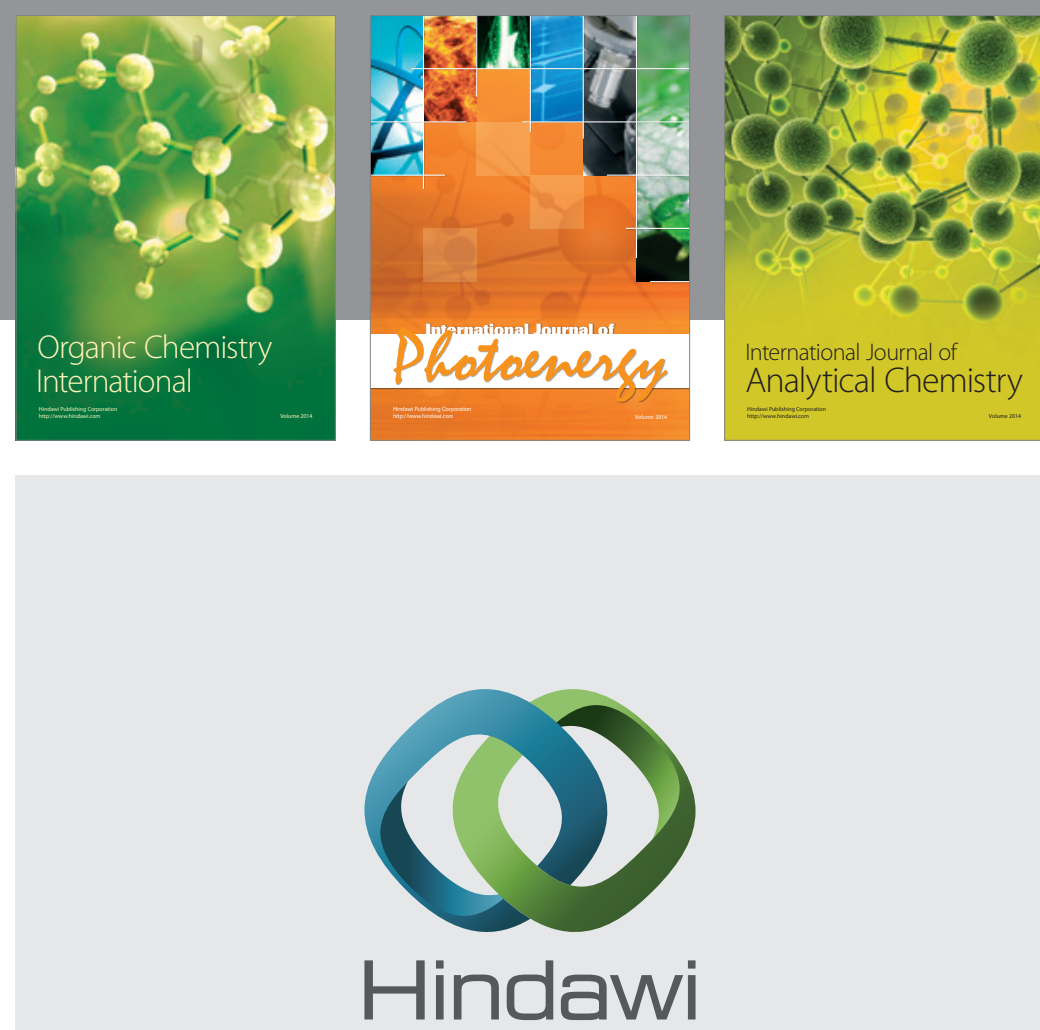

Submit your manuscripts at

http://www.hindawi.com
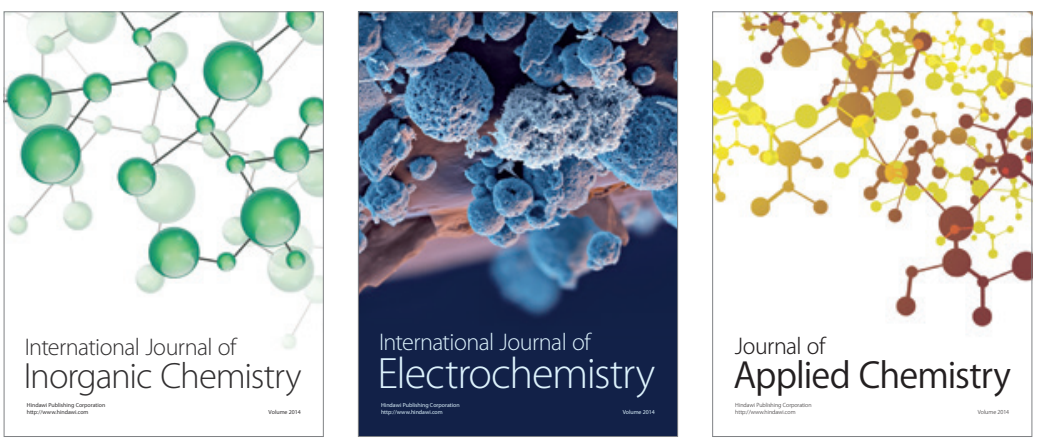

Journal of

Applied Chemistry
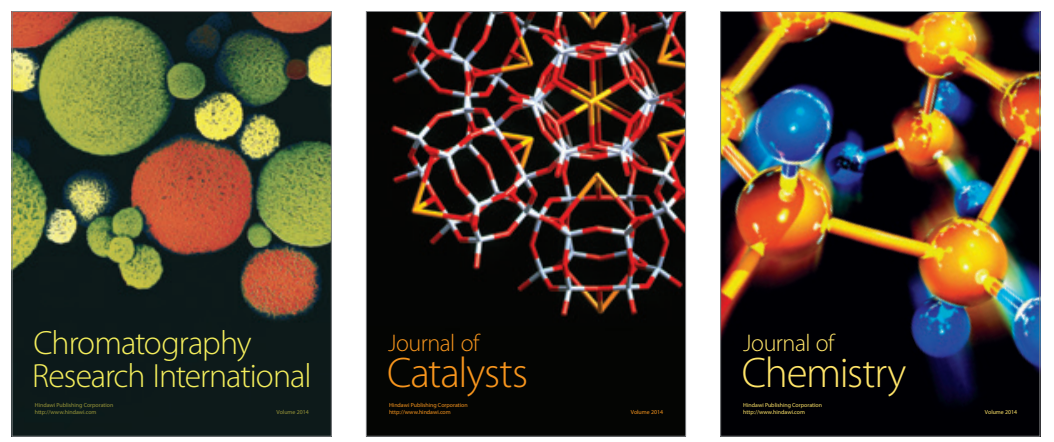
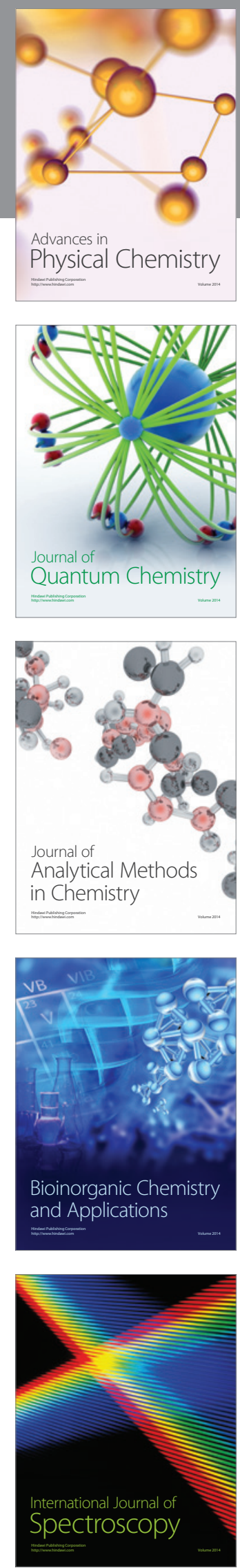